MATHEMATICS OF COMPUTATION

Volume 76, Number 257, January 2007, Page 507

S 0025-5718(06)01908-9

Article electronically published on September 19, 2006

\title{
A COMPOSITENESS TEST THAT NEVER FAILS FOR CARMICHAEL NUMBERS
}

\author{
ANDREW D. LOVELESS
}

Abstract. Paper withdrawn by author after original electronic posting date of September 19, 2006 and prior to preparation of the printed issue.

Department of Mathematics, University of Washington, Box 354350, Seattle, WashINGTON $98195-4350$

Received by the editor September 30, 2005.

(C)2006 American Mathematical Society 